\title{
Views of Pre-service Teachers Related to the Development of Pedagogical Formation Training and Design Competences
}

\author{
Mehmet Özbaş, ${ }^{1, *}$, Dinara Mukhatayeva \\ ${ }^{1}$ Department of Educational Sciences, Faculty of Education, Erzincan University, Erzincan, Turkey \\ ${ }^{2}$ Faculty of Philosophy and Political Science, al-Farabi Kazakh National University, Almaty, Republic of Kazakhstan
}

Copyright $\bigcirc 2018$ by authors, all rights reserved. Authors agree that this article remains permanently open access under the terms of the Creative Commons Attribution License 4.0 International License

\begin{abstract}
The importance of pedagogical formation training is remarkable for developing the professional competences of pre-service teachers. One of the basic functions of pedagogical formation is getting pre-service teachers have competences on teaching design through cooperative learning experiences in a social learning environment. During higher education, in-class experiences generally include socio-pedagogical learning processes fulfilled under the guidance of lecturers. The purpose of this research was to determine the views of pre-service teachers related to the development of pedagogical formation training and design competences. The research was carried out with 428 pre-service teachers who had pedagogical formation training in Erzincan University in 2016-2017 academic year. "The Scale for Pedagogical Formation Training, and Developing Design Competences of Pre-Service Teachers" was developed by the researchers. During the process of scale development, pre-implementation was administered with the participation of 83 pre-service teachers, and the scale was determined to have 2 factors. Total variance explained by the factors was $61.695 \%$; and alpha reliability coefficient for the first factor was .923 , and it was found to be .863 for the second factor. According to research findings, it was noticed that the perceptions related to the factor of "the quality of pedagogical formation training" had "high" level, and the perceptions related to the factor of "development of teaching design competences" had "medium" level performance.
\end{abstract}

Keywords Pre-service Teacher, Design Competence, Socio-pedagogical Support, Pedagogical Formation Training

\section{Introduction}

The level of meeting the need for qualified teacher is one of the most fundamental development indicators of democratic educational systems. The main quality dimensions that teachers should have are general culture and pedagogical formation competences [1, 2, 3, 4, 5]. Pedagogical formation training is the process of training pre-service teachers with efficient teaching skills. The pre-service teachers primarily acquire the knowledge of teaching profession through the pedagogical formation training. This process is the system of transforming professional knowledge into competence and skills for pre-service teachers. Pedagogical formation training is a process in which pre-service teachers are provided to acquire efficient multi-dimensional skills for training their students according to their branches.

Pedagogical formation training includes the whole multi-variable implementations for getting pre-service teachers acquire efficient knowledge and skills on teaching profession. Through the pedagogical formation training, pre-service teachers are aimed to transform their theoretical knowledge and general culture into skills necessary for their profession. This process is basically carried out for getting pre-service teachers have competences of training in a multi-dimensional and efficient way. In a democratic educational system, pre-service teachers are ensured to gain any kinds of individual skills related to their profession during the process of pedagogical formation training. Pre-service teachers are trained not through a generalized perception, but through individualized teaching opportunities considering their social learning experiences and academic learning processes. During their university education process, pre-service teachers are provided to acquire abilities and skills that help develop their potentials in their 
branches, general culture, and their pedagogical formation competences. The skills related to their design competences on how they will fulfill teaching process are also thought. The importance of socio-pedagogical support is essential in developing the design competences of pre-service teachers. Socio-pedagogical support is generally ensured during the process of gaining cooperative learning experiences during the university education. The pre-service teachers are provided to acquire cooperative learning opportunities through face-to-face education during their university education. In this sense, the importance of formal education is remarkable especially in teacher training implementations. Instructional design competences are provided to the pre-service teachers not through "distance education," but through face-to-face education.

The most important skills for the pre-service teachers to acquire in academic learning processes include competences related to how they will design teaching activities. Teaching process is basically a design system. Design competences to be acquired by the pre-service teachers during the university process include studies related to practices. Pre-service teachers can learn design competences through experiencing. In this sense, it is necessary for pre-service teachers to acquire learning competences through experiencing for teaching design. The activities should be performed in theory-practice unity in order for teaching design competences. For that reason, in-class experiences of pre-service teachers in university educational processes should be designed as appropriate to the real life. Teaching design competence includes properties possible to be acquired through natural learning experiences away from artificiality. In teaching design process, "individual-centered practices" are provided to be performed for getting the pre-service teachers to acquire multi-dimensional competences. Necessities of teaching profession as its basic function is teaching are so fulfilled within academic implementations. The student is the presence of being of a democratic educational system, in general, and of school and classroom, in special. In this sense, one of the most important roles of an educational system is to provide students to learn and to guide them. In educational system, teachers have the role of teaching. The importance of qualified teaching is remarkable for learning of students. Fulfilling the teaching activities at an intended level is one of the indicators of efficient schools. For that reason, teaching profession has a vital importance for creating efficient schools.

One of the most important two human sources of a democratic educational system is teaching profession. Teaching skills are tried to be acquired by the pre-service teachers with a universal understanding during their university education. In this sense, pluralist socio-pedagogical function of pedagogical formation training that provides democratic competences has a remarkable importance. Socio-pedagogical education could be provided creating group experiences and cooperative learning opportunities. Cooperative learning implementations include the activities that provide pre-service teachers to have democratic and pluralist teaching skills.

Teachers are one of the most important human resources responsible for the effective performance of teaching activities in the education process through learning-teaching activities, and they provide support in many ways, such as educating people, teaching and guiding them, giving direction and preparing for life [6], and integrating various tasks or activities and teaching approaches in educational process [7]. In order for teachers to be able to fulfill their roles and duties as required within the framework of powers and responsibilities they primarily need to possess the competencies and standards required for the profession of teaching. For teachers, pedagogical formation training is the processes of getting students acquire design competences. Socio-pedagogical support is provided to the pre-service teachers during the process of cooperative learning experiences. For that reason, pre-service teachers are required to accept their being a member of social groups. The skill of learning in groups is one of the fundamental functions of socio-pedagogical support implementations. Through the socio-pedagogical support implementations, pre-service teachers acquire the values of professional socializing. When pre-service teachers start carrying on their profession, they can fulfill implementations that provide their students to be a member of a social group.

Teachers of the $21^{\text {st }}$ century, before anything else, should transfer their knowledge on teaching profession into their competences of training in their professional life and their classroom management skills. Pedagogic Formation Training is an applied process of training which provides professional skills necessary for pre-service teachers all over the world. In this process, basic design competencies regarding the implementation of teaching in classroom environment are provided for pre-service teachers $[1,5,8$, $9,10,11,12]$. The competences related to teaching design can be provided to be gained by the pre-service teachers through pedagogical formation training. For designing the instructional processes, pre-service teachers are provided to acquire skills internalizing the values of teaching profession. And importance of pedagogical formation training is remarkable for providing pre-service teachers acquire the values of teaching profession.

The teachers have the responsibility of transferring any kinds of potential of their students into "positive" behaviors. Nearly in all educational grades, teachers can develop the potentials of their students benefiting from pedagogical formation competences they have. The implementations related to teacher training processes are transformed into cognitive, emotional, and psycho-motor competences and qualifications through learning experiences. The activities in which training skills based 
upon competences and qualifications of the teachers are included in "pedagogical formation training" administered during the higher education process $[13,14]$. It is possible to suggest that one of the most important problems experienced in democratic educational systems all around the world is related to teacher training processes. Democratic management systems have to carry out development policies based primarily upon education in order to provide permanent social development. In this sense, democratic countries have to develop national standards related to how and in which way qualified teachers of all branches should be trained. National teacher training strategies and standards are also required to meet accreditation through international teacher qualifications and criteria. It has been suggested that accreditation, competency, and standards regarding the profession of teaching are associated to two different functions complementing and supporting each other and these functions are "the pre-service academic training and in-service socialization processes of teachers". Providing special teaching skills to the pre-service teachers according to branches is a significant requirement. Different teaching profession branches have properties requiring competences specific to their own. These differences should be provided for pre-service teachers to be acquired during their pedagogical formation training. Teaching knowledge and skills are acquired through branch-specific academic learning activities. During the pedagogical formation process, pre-service teachers have profession-specific training skills. Pedagogical competences are tried to be taught to the pre-service teachers through special teaching methods, teaching technologies, material design lessons or other activities.

\section{Problem Status}

One of the most fundamental indicators of an efficient educational system is to achieve permanence in implementations that meet qualified teacher need in any grades and branches. And meeting the need for qualified teachers depends primarily upon successful training of pre-service teachers during higher education process. Problems regarding the profession of teaching cannot be solved by isolating teachers from the academic training processes. On the other hand, scientific studies should discuss whether or not teaching staff can prepare prospective teachers for the practice stage of the Turkish education system in terms of both the performance levels and teaching competencies. Pre-service teachers are required to gain sustainability considering the efficiency and productivity principles of academic education. This approach requires the implementation of successful educational management in teacher training system.

The implementations that makes efficient teacher training more successful and sustainable are provided through fulfilling general culture, and pedagogical formation trainings in a way meeting the requirements of social change and development. Especially pedagogical formation training has a remarkable place in perception and acceptance of teaching as a profession. Pedagogical formation training and competences related to teaching design acquired by the pre-service teachers are critical implementations providing teaching to professionalize. When Turkey has been discussed in terms of the educational system, the most important implementation that prevents teaching to professionalize is the practices of assignment for the acceptance of teaching profession requiring expertise. In turkey, individuals who have had academic educational except from teaching profession are also assigned. This negatively affects social status and value of teaching profession. There are no legal sanctions against these non-professional assignments, individuals of teaching profession do not react in an efficient and organized democratic way. One of the most important factors for not creating an efficient democratic public opinion for teaching as a profession is having no association in teaching profession. Whereas there are collecting societies for the professions such as medicine, architecture, engineering, public accountancy, etc. that offer common standards and conditions, there is no collecting society for teaching profession. Pedagogical formation training that should be the pre-condition of teaching profession include the whole of implementations that provide professional awareness for the pre-service teachers. Pre-service teachers can acquire professional and organizational socializing skills through the pedagogical formation trainings. One of the most important necessities of Turkey's taking place among the democratic and developed countries includes teacher training implementations provided international accreditation conditions. Educated individuals trained by qualified teachers are one of the most important triggering strengths of social development.

The teacher training process in the world mostly depends upon tertiary education. During the tertiary education, teacher training implementations are primarily required to be in accordance with democratic and national standards. Furthermore, national standards should also meet the international standards. International teacher training standards primarily require teachers' being a democratic role model for their students. In this sense, Turkish educational system should rapidly put implementations providing pre-service teachers to be a democratic role model into practice. International accreditation of educational faculties playing efficient roles during the teacher training process in Turkey should also be provided.

A lot of problems are encountered in the process of the development of pre-service teachers. The most important of these problems can be stated as "can pedagogic formation programs provide teaching skills for pre-service teachers?", "can pre-service teachers develop the design 
skills for teaching process through pedagogic formation education?", and can pedagogic formation education meet the demand for contemporary change?"

The implementations related to teacher training system and the problems related to not meeting the need for qualified teacher at any grades and branches are among the most significant problems of Turkish educational system. In the context of the effectiveness of public administration in Turkey, it is an administrative obligation for the Ministry of National Education to lead studies covering the topics of effectiveness and efficiency for the purpose of reflecting the current condition of the education system $[2,15,16$, 17]. According to Yılmaz and Güneş [18], the certificate programs are necessary for promoting teacher, however some of the students enrolled to the certificate programs for pedagogical formation found it necessary, whereas the others found it inadequate and unnecessary. Nartgün [19] carried out a study on Pedagogical Formation Students' Perceptions about Employment and Teaching Profession and found out that the students did not believe in the benefits of the program, as they had read and learned the info provided in the graduate program before the Pedagogical Formation courses, while the others who believed in the benefits of the program pointed out that they already worked as substitute teachers with pay and they would continue doing so however they would be better teachers with the help of the current program they were attending. Argon and Sezen-Gültekin [20] argued that formation students are the teachers of the future and teachers are the role models for students. They maintained in the study that the finding of low moral maturity is conspicuous and unfortunately negative.

Democratic management systems that aim to make education as an instrument of total social development also experience similar problems. The Educational Faculties in Turkey have played a key role during teacher training process. However, it has been noticed that other faculties apart from the educational faculties sometimes intervene into teacher training system in Turkey. Apart from the educational faculties, "the faculties of arts and science, engineering, economics and administrative sciences, theology, law, etc.," and some other vocational schools have also been noticed to intervene into the process of teacher training implementations.' However, prospective secondary education teachers graduating from higher education institutes other than faculties of education are required to meet the condition of pedagogical formation. It is ensured that pedagogical formation is provided through faculties of education; however, it can be observed that this training is inadequate in comparison to the training received by prospective teachers in faculties of education in both qualitative and quantitative respects [21, 22, 23]. Except from these, some teaching profession branches, primarily classroom teaching department, have fulfilled some implementations in which postgraduates out of the domain are accepted to the teaching branches. Assignment out of teaching domain is an approach that makes teaching profession invaluable and inefficient. This approach does not concern the people out of real teaching professionals including whole qualifications of teaching profession. Out-of-domain assignments turn teaching profession into a factor of employment that provides job for university graduates.

\subsection{Purpose}

During the process of training pre-service teachers, the implementations with vital importance depend upon fulfilling teaching processes related to pedagogical formation training in accordance with the purposes. Pedagogical formation process is whole of multi-dimensional implementations that gets teachers have competences on teaching design as well as professional development.

Academic training process and practices within educational experiences of pre-service teachers can be assessed within the framework of preparation to profession. It is necessary to determine efficiency of academic training processes with scientific researches during the university education of the pre-service teachers. Furthermore, it is necessary to carry out further researches on whether teaching implementations that had preparing role for pre-service teachers are fulfilled with faculty-school cooperation and whether these are appropriate for the professional standards.

During the pedagogical formation process, fulfilling necessary administrative and academic implementations is essential in terms of training pre-service teachers to have a full knowledge on information, communication and teaching technologies. For that reason, gaining design competences related to managing and organizing the teaching process should have primarily been adopted by pre-service teachers. In order for teachers, cooperative socio-pedagogical support implementations are needed to transfer their training competences into the teaching process. In the study we aimed to reveal to what extent implementations related to teaching design that were required to be gained by pre-service teachers during the educational process through pedagogical formation training were fulfilled. In this context, we tried to find out answers to the questions of "what are the views of pre-service teachers on the education of pedagogical formation?" and what are the views of pre-service teachers on the development of design competencies?"

\section{Materials and Methods}

\subsection{Research Model}

The descriptive and comparative research method was used in the study. In the research, pre-service teachers who 
graduated from any programs except from educational faculties were asked to express their opinions on the quality of pedagogical formation training.

\subsection{Research Universe and Sampling}

The research was carried out with 428 pre-service teachers who had pedagogical formation training in Erzincan University in 2016-2017 academic year.

\subsection{Research Scale}

The research scale was developed revising the scale used in the research titled as "Teacher and Administrator Perceptions on the Pre-Service Academic Training and In-Service Socialization Processes of Teachers" that was carried out by Burgaz and Özbaş [2]. The scale used by Author was redesigned for this research. During the process of developing this scale for this research, validity and reliability analyses were re-performed. The new scale was updated in a way meeting the current needs. During the process of developing the scale, assessments of the academicians who studied in education management were asked, and necessary tests were performed for the content validity. In accordance with the critiques of the academicians, 6 out of 27 items in the draft form were excluded. In terms of developing the scale, pre-implementation was performed with 83 pre-service teachers. In order to determine construct validity on pre-implementation data, factor analyses were carried out. In the analyses, $\mathrm{KMO}$ value of the scale was found to be .939 . For specifying whether the scale was mono- or multi-factor, Varimax vertical rotation method was used. As result of this analysis, the scale was noticed to have a two-factor structure. Total variance explained by the factors was determined to be $61.695 \%$; and alpha reliability coefficients were found to be .923 and .863 . Six items that were noticed to be out of the scope of 2 factors of the scale were excluded from the study. Explained total variance in the first scale used by Burgaz and Özbaş [2] was $41.828 \%$. The reliability coefficient in the scales of Author was $92 \%$ for the first factor and $86 \%$ for the second factor. In Table 1, variance rates and Cronbach Alpha reliability coefficients for the factors of the scale were presented.

Table 1. Variance Rates and Cronbach Alpha Coefficients of the Pedagogical Formation Training and Acquisition of Design Competences Scale to the Factors

\begin{tabular}{|c|c|c|}
\hline Factor & $\begin{array}{c}\text { Explained } \\
\text { Variance \% }\end{array}$ & $\begin{array}{c}\text { Cronbach } \\
\text { Alpha }\end{array}$ \\
\hline $\begin{array}{c}\text { Pedagogical Formation } \\
\text { Training }\end{array}$ & 34.793 & 923 \\
\hline $\begin{array}{c}\text { Development of Teaching } \\
\text { Design Competences }\end{array}$ & 26.902 & 863 \\
\hline
\end{tabular}

The students with regular attendance to the pedagogical formation training program were regarded for determining the pre-service teachers to be included into the research. Totally 512 out of 754 students were determined to attend into the pedagogical formation training as full-time. The scales were performed to whole 512 pre-service teachers who had regular attendance. The research scale was performed upon 428 pre-service teachers who had pedagogical formation trainings from different teaching branches. In the scale, there were 15 items prepared with 5-point Likert approach. There were 10 items in "Quality of Pedagogical Formation Training Implementations" factor of the scale, and there were 5 items in "Gaining Teaching Design Competences" factor. Descriptive statistics techniques were benefited for the analysis of the descriptive data in the research. T-test was used for analyzing the data related to the independent variables of the research, and one-way variance analysis was used for comparing the variables more than 2 parametric test assumptions. For revealing the difference appeared as result of one-way variance analyses, multiple comparison statistics were benefited. In statistical processes, the level of significance was accepted to be .05 .

\section{Findings and Interpretation}

According to the findings obtained in this research, the average for the perceptions of the pre-service teachers related to "Quality of Pedagogical Formation Training Implementations" factor was $\overline{\mathrm{X}}=3.48$. Pre-service teachers considered this implementation of the pedagogical formation training as adequate at "high" level. However, this rate was away from reflecting the ideal level. Pre-service teachers considered the activity of "Lecturers who carry on their duties during the process of pedagogical performance use teaching time efficiently" adequate at "high" level ( $\bar{X}=3.78$ ). This finding could be evaluated in a way that time was used efficiently and productively during the process of pedagogical formation classroom management. The lowest performance during the pedagogical formation training performance was considered for the activity of "pedagogical formation training provided me to be ready for teaching profession" ( $\overline{\mathrm{X}}=3.27$ ). This finding could be interpreted as pre-service teachers' regard the period and process of pedagogical formation training as inefficient and inadequate.

As could be seen in Table 2, the pre-service teachers mentioned that "face-to-face implementations positively affected their teaching skills" ( $\bar{X}=3.63)$. This finding revealed that formal and face-to-face education maintained in university grades provided efficient competences for the pre-service teachers in teaching implementations. This finding also indicated that qualified pedagogical formation training was much more successful rather than the pedagogical formation training maintained under the title of "distance education." According to the pre-service teachers, pedagogical formation training was an 
implementation that could increase the success of teachers $(\bar{X}=3.52)$. This finding proved that pre-service teachers considered pedagogical formation training as an implementation that could make significant contributions upon professional development and performance.

Table 2. Views of Pre-Service Teachers Related to Pedagogical Formation Training $(\mathrm{n}=428)$

\begin{tabular}{|l|c|c|}
\hline \multicolumn{1}{|c|}{ Items } & $\bar{X}$ & SD \\
\hline 1. Teaching time was used efficiently & 3.78 & 98 \\
\hline $\begin{array}{l}\text { 2. Face-to-face education positively } \\
\text { affected my teaching skills. }\end{array}$ & 3.63 & 1.02 \\
\hline $\begin{array}{l}\text { 3. Pedagogical formation improves the } \\
\text { achievements of teaching profession. }\end{array}$ & 3.52 & 1.07 \\
\hline $\begin{array}{l}\text { 4. Equality of possibility and opportunity } \\
\text { should be created during the } \\
\text { pedagogical formation }\end{array}$ & 3.42 & 1.03 \\
\hline $\begin{array}{l}\text { 5. Pedagogical formation curriculum is } \\
\text { appropriate to the needs of the } \\
\text { pre-service teachers. }\end{array}$ & 3.41 & 1.04 \\
\hline $\begin{array}{l}\text { 6. The period for the pedagogical } \\
\text { formation training is adequate. }\end{array}$ & 3.37 & 1.06 \\
\hline $\begin{array}{l}\text { 7. The pedagogical formation process } \\
\text { prepares pre-service teachers to their } \\
\text { profession. }\end{array}$ & 3.27 & 1.13 \\
\hline
\end{tabular}

As could be seen in Table 2, the pre-service teachers considered that the function of "creating the equality of opportunity and possibility during the pedagogical formation training process" (3.42) could not be fulfilled. This finding proved that opportunities and possibilities could not be provided equally to the pre-service teachers during the pedagogical formation training process. Equal opportunities and possibilities in terms of teaching and student personality services, social activities, recreation facilities and teaching technologies could not be created. Furthermore, the pre-service teachers considered that the program was not adequate in terms of both needs (3.41) and period. This revealed that pedagogical formation training was not based upon a needs analysis.

In Table 3, the data related to the "development of teaching design competences," as the $2^{\text {nd }}$ factor of the scale, were presented. The design competence included the implementations that were performed for getting pre-service teachers gain professional skills. According to the findings obtained from this research, the implementations related to developing the design competences of the pre-service teachers $(X=3.37)$ were fulfilled at a "medium" level. This finding indicated that design competences of the pre-service teachers were regarded at "medium" level. In fact, the teachers should be entrusted with the highest possible performance and competences in terms of instructional design. In design competences factor, the highest performance of the pre-service teachers was on "academicians positively affected the use of educational opportunities" (3.68). The academicians provided pre-service teachers to benefit from the educational opportunities at "high" level through various guidance and orientation activities.

Table 3. The Views of Pre-Service Teachers upon the Development of Design Competences $(n=428)$

\begin{tabular}{|l|c|c|}
\hline \multicolumn{1}{|c|}{ Items } & $\bar{X}$ & SD \\
\hline $\begin{array}{l}\text { 8. Academicians positively affect the use } \\
\text { of educational opportunities. }\end{array}$ & 3.68 & 1.02 \\
\hline $\begin{array}{l}\text { 9. Pedagogical formation process is } \\
\text { organized according to my needs. }\end{array}$ & 3.37 & 1.19 \\
\hline $\begin{array}{l}\text { 10. Pedagogical formation process meets } \\
\text { my expectations. }\end{array}$ & 3.35 & 1.09 \\
\hline $\begin{array}{l}\text { 11. Properties of the pre-service teachers } \\
\text { are regarded in teaching competences }\end{array}$ & 3.22 & 1.08 \\
\hline $\begin{array}{l}\text { 12. Socio-pedagogical support should be } \\
\text { given on teaching competences. }\end{array}$ & 3.21 & 1.17 \\
\hline
\end{tabular}

The pre-service teachers perceived the factor of "Gaining Teaching Design Competences" at $\bar{X}=3.37$ level. According to this, design competence was provided to be gained by the pre-service teachers at "medium" level. The lowest performance $(\overline{\mathbf{X}}=3.21)$ at design competence dimension was on the activity of "providing socio-pedagogical support to pre-service teachers for getting them gain teaching design competences." This finding was an evidence for the fact that lecturers could not create social learning opportunities for the pre-service teachers through cooperative learning opportunities. Still maintaining classical teaching approaches and not implementing "the style of learning through experiences" could be efficient upon this finding to appear.

For the factor of developing design competences, the lowest performance was on "providing socio-pedagogical support" $(\bar{X}=3.21)$. During the process of developing the design competences, cooperative learning implementations were fulfilled at "low medium" level. This finding also confirmed the finding that "traits of the pre-service teachers should be regarded for teaching design" (3.22). Pedagogical formation training could not adequately meet the expectations of the pre-service teachers (3.35). These values indicated fairly inadequate averages for getting pre-service teachers acquire the skills of constructing the learning efficiently.

No statistically significant differences were determined in paired and multiple comparisons related to views of the pre-service teachers. The reason for these finding to appear was pre-service teachers' perceiving the development of design competences and pedagogical formation training at "medium" level. Pre-service teachers' having pedagogical formation training after their bachelor's degree graduation or at a period close to their graduation was possible to create these findings. Namely, all pre-service teachers had the pedagogical formation training after gaining "special field and general culture" competences. The pre-service teachers who graduated from other faculties except from 
the educational faculties in Turkey have had pedagogical formation training after having necessary pre-conditions related to their undergraduate education. This provided pre-service teachers to have specific competences before their pedagogical formation trainings.

It was found in this research that face-to-face teaching had a remarkable role in teacher training. Namely, "distance education" was not an efficient method during the process of teacher training. According to the research findings, pedagogical formation training was determined to be an implementation that would increase the success of teachers. In the research, instructional design competences of pre-service teachers were determined not to be developed at an expected level. Socio-pedagogical support could not be provided during the process of developing teaching design.

\section{Conclusions and Suggestions}

According to the results obtained from Pedagogical Formation Training and Teaching Design Research, pedagogical formation training is an implementation that is possible to provide pre-service teachers gain the skills of teaching profession. Efficiency of this implementation is especially arisen from its organization through a formal education approach. Different implementations that make distance education or formal education opportunities negative make pedagogical formation training nonfunctional. Pedagogical formation training is inefficient upon getting pre-service teachers gain cooperative socio-pedagogical design competences. In pedagogical formation training, curriculum enhancement should be provided in order to develop teaching design competences. Pre-service teachers should maintain their pedagogical formation training as full-time and efficient sanctions on this should be imposed.

Pedagogical formation training is the whole of universal implementations that help pre-service teachers gain multi-dimensional competences [24, 25, 26]. Through the pedagogical formation trainings, pre-service teachers learn to transform their general culture and special field potentials into training skills. The academicians have to be democratic teacher models for the pre-service teachers. Teaching profession is taught to the pre-service teachers through the understanding of "learning by experiencing." In this study, the pedagogical formation training and to what extent the design competences could be developed were tried to be determined. It was determined in this research that the most important function of pedagogical formation training was to get pre-service teachers acquire teaching design skills.

During the academic training processes of pre-service teachers, development of design competences is a fundamental and professional need. The whole of academic implementations in which teaching design competences of pre-service teachers are fulfilled include an operational process with vital importance. Design implementations are the evidence and indicator of skills for the pre-service teachers. Regarding the design knowledge and skills of pre-service teachers and performing required training activities provide to establish theory-practice integrity. Acquiring design competences primarily make pre-service teachers have the strength of planning and organizing teaching. Design competences also help pre-service teachers to be away from the worries of not organizing and implementing teaching. Teaching profession is a branch in which pre-service teachers have through teaching. Teaching design is a system of activities making pre-service teachers to acquire the competence of learning by experiencing. However, it was determined in this research that pre-service teachers could not acquire design competences at a level that could meet the expectations. During the research process, it was revealed that pedagogical formation training of the pre-service teachers was not based upon a real needs analysis. This also caused the academic processes providing design competences to be obtained by pre-service teachers not to be successful.

In the research, it was emphasized that pedagogical formation should be focused mainly on social learning. It is necessary to establish cooperative team groups, each consisting of three or four individuals, so as to promote the possibilities of learning with group in teacher education. Cooperative learning is an application process that develops teacher leadership. Academicians should also be competent educational leaders for adequately providing cooperative learning competences.

One of the most important functions of pedagogical formation training is to provide pre-service teachers gain the competences of designing learning-teaching experiences. However, it is necessary for pre-service teachers to practice branch-based implementations during the process of gaining design competences. In teaching training, which educational process the pre-service teachers need, should primarily be determined through the needs analysis. In developing design competences of pre-service teachers, theory-practice integrity is tried to be provided. Furthermore, model implementations in cooperation are provided to be performed to the pre-service teachers according to their branches. The pre-service teachers are ensured to acquire pre-experiences through real learning experiences in practice schools. The pedagogical formation training and design competences research revealed the importance of face-to-face education. Research results indicated that the pedagogical formation training could not be fulfilled in accordance with the needs of pre-service teachers. Pedagogical formation training was not carried out depending upon a needs analysis. Not performing "needs analysis" determining the educational needs of pre-service teachers before starting to pedagogical formation training was a remarkable deficiency.

According to the research results, pedagogical formation 
training, in general, aims to prepare pre-service teachers for teaching profession. However, pedagogical formation training cannot fulfill having the quality of being an efficient process in practice. The research results indicated that pedagogical formation training was not fulfilled depending upon the results of a needs analysis. In pedagogical formation training, the academicians have efficiently used the time. During the design processes, the academicians positively affected the use of educational opportunities. It was concluded in the research that instructional design practicing skills of pre-service teachers could not be improved. It was also concluded that cooperative learning practices through the socio-pedagogical support implementations could not be developed. Face-to-face education was more efficient in pedagogical formation training. In this research, pedagogical formation training was determined not to provide the opportunities for socio-pedagogical training. It was revealed that teaching design was a process requiring significant competences and abilities in pedagogical formation training. In design competences factor of the research, the requirement for training of the pre-service teachers according to their branches through different and specific understandings was revealed.

According to the research results, the suggestions below were offered:

- Pedagogical formation training was developed depending upon the results of "needs analysis."

- Teacher training implementations can be assessed with internationally comparative researches.

- Pre-service teachers' skills of managing the teaching processes should tried to be provided through socio-pedagogical support implementations.

- In pedagogical formation training, "full-time attendance" of the pre-service teachers to the teaching processes should be provided.

- Individual teaching implementations that will develop teaching design competences of the pre-service teachers should be emphasized.

- Validity of teacher training implementations can be discussed in national or international researches.

- More comprehensive researches should be carried out for determining the total satisfaction levels of pedagogical formation training in Turkey.

\section{REFERENCES}

[1] Aydoğdu, A. (2015). Öğretim elemanlarının sınıf yönetimi beceri düzeyleri. Yayımlanmamış Yüksek Lisans Tezi. Harran Üniversitesi Sosyal Bilimler Enstitüsü Eğitim Bilimleri Anabilim Dalı, Eğitim yönetimi ve Denetimi Bilim Dalı. Turkey: Şanlıurfa.

[2] Burgaz, B. \& Özbaş, M. (2016). Teacher and administrator perceptions on the pre-service academic training and in-service socialization processes of teachers. KASMERA Journal (ISSN: 0075-5222). Kasmera Journal, 44, 1, pp. 278-293.

[3] Hattie, J. C. (2009). Visible learning: A synthesis of over 800 meta-analyses relating to achievement. London \& New York: Routledge, Taylor \& Francis Group.

[4] Mc Namara, D. (1995). The influence of student teacherse tutors and mentors upon their classroom practice: an exploratory study. Teaching \& Teacher Education, 11, pp. 51- 61 .

[5] Özbaş, M. \& Arslan, M. A. (2016). Views of Turkish Language and Literature teachers and their managers related to professional and organizational socialization processes of Turkish Language and Literature teachers. International Education Studies; Vol. 9, No. 3. ISSN 1913-9020 E-ISSN 1913-9039, pp. 81-88. doi:10.5539/ URL: http://dx.doi.org/10.5539/

[6] Kayalar, F. \& Güler Ar1, T. (2017). The Strategies of Veteran Teachers for Engaging Students in Learning Activities in Classroom Environment. International Journal of Management and Applied Science, Volume-3, Issue-9, Sep.-2017

[7] Kayalar, F. \& Kayalar, F. (2017). The effects of Auditory Learning Strategy on Learning Skills of Language Learners (Students' Views). IOSR Journal Of Humanities And Social Science (IOSR-JHSS), Volume 22, Issue 10, Ver. VII (October. 2017)

[8] Kamens, M. W. (2007). Learning about co-teaching: A collaborative student teaching experience for preservice teachers. Teacher Education and Special Education, 30, 3, pp. $155-166$

[9] Kohen, L. (2006). Etkili sınıf yönetimi için uygun sınıf ortamının yaratılmasında öğrenci ve öğretmen beklentileri (İstanbul'daki üniversitelerden bir uygulama). Yayınlanmamış Yüksek Lisans Tezi. Yeditepe Üniversitesi Eğitim Bilimleri Enstitüsü. Turkey: İstanbul.

[10] OECD. (2009). Creating effective teaching and learning environments: First results from TALIS. Paris: OECD.

[11] Şandır, H. (2010). Matematik öğretmen ve öğretmen adaylarının tasarladıkları ve uyguladıkları modellemelere ait süreçlerin incelenmesi. Yayımlanmamış Doktora Tezi. Gazi Üniversitesi Eğitim Bilimleri Enstitüsü Ortaöğretim Fen ve Matematik Alanlar Eğitimi Matematik Öğretmenliği Bilim Dal1. Turkey: Ankara.

[12] Uslu, D. (2012). Almanca öğretmenliği bölümlerinde verilen formasyon ve alan derslerinin ilk ve ortaögretime uygunluğu. Yayımlanmamış Yüksek Lisans Tezi. Çukurova Üniversitesi Sosyal Bilimler Enstitüsü, Alman Dili Eğitimi Ana Bilim Dal1. Turkey: Adana.

[13] Johnson, L. E. (2008). Teacher candidate disposition: Moral judgement or regurgitation? Journal of Moral Education, 37, 4, 2008, pp. 429-444.

[14] Tınmaz, A. K. (2013). Öğrenci görüşlerine göre öğretim elemanlarının pedagojik yeterlikleri. Yayımlanmamış Yüksek Lisans Tezi. Ondokuz Mayıs Üniversitesi Eğitim Bilimleri Enstitüsü Eğitim Bilimleri Anabilim Dalı, Eğitim Yönetimi, Teftişi, Planlaması ve Ekonomisi Bilim Dalı. Turkey: Samsun. 
[15] Karagözoğlu, G. (2008). Türk eğitim siteminde öğretmen yetiştirme çıkmazımız. Çağdaş Eğitim Dergisi, 349, 1, pp. 3-7.

[16] Karal Eyüboğlu, I. S. (2011). Fizik öğretmenlerinin pedagojik alan bilgi (pab) gelişimi. Yayımlanmamış Doktora Tezi. Karadeniz Teknik Üniversitesi Eğitim Bilimleri Enstitüsü Ortaöğretim Fen ve Matematik Alanları Eğitimi Anabilim Dalı Fizik Eğitimi Bilim Dalı. Turkey: Trabzon.

[17] Saks, A. M. \& Ashforth, B. E. (1997). Socialization tactics and newcomer information acquisition. International Journal of Selection and Assessment, 5, 1, pp. 48-61.

[18] Yılmaz, R. \& Güneș, M. H. (2017). Reasons of Pedagogical Formation Education Certificate Program Students Taking This Education: Comparison of Different Departments. Universal Journal of Educational Research 5(12): 2320-2330, 2017. DOI: 10.13189/ujer.2017.051223

[19] Nartgün, Ş. S. (2016). Pedagogical Formation Students' Perceptions about Employment and Teaching Profession. Universal Journal of Educational Research 4(12A): 22-30, 2016. DOI: $10.13189 /$ ujer.2016.041304

[20] Nartgün, Ş. S. (2016). Pedagogical Formation Students' Perceptions about Employment and Teaching Profession. Universal Journal of Educational Research 4(12A): 22-30, 2016. DOI: $10.13189 /$ ujer.2016.041304

[21] Baki, A. (2009). Türkiye'de alan öğretmeni yetiştirme programlarının ve politikalarının değerlendirilmesi. Eğitimde Yansımalar IX: Türkiye'nin Öğretmen Yetiştirme
Cikmazı Ulusal Sempozyumu (ss. 56-65). Başkent Üniversitesi Avni Akyol Konferans Salonu 12-13 Kasım 2009. Ankara: Öğretmen Hüseyin Hüsnü Tekışık Eğitim Araştırma Geliştirme Vakfı Yayınları.

[22] Karagözoğlu, G. (2009). Türkiye'de öğretmen yetiştirme uygulamalarına genel bakış. Eğitimde Yansımalar IX: Türkiye'nin Öğretmen Yetiştirme Çıkmazı Ulusal Sempozyumu (pp. 11-18). November 11-12, 2009 Ankara: Öğretmen Hüseyin Hüsnü Tekışık Eğitim Araştırma Geliştirme Vakfı Yayınları.

[23] ÖSYM. (2012). 2012 Öğrenci Seçme ve Yerleştirme Sistemi (ÖSYS) Kılavuzu. Ölçme Seçme ve Yerleştirme Merkezi. Turkey: Ankara.

[24] Ekinci, A. (2010). Aday öğretmenlerin iş başında yetiştirilmesinde okul müdürlerinin rolü - Roles of headmasters on the job-training of the pre-service teachers. Dicle Üniversitesi Ziya Gökalp Eğitim Fakültesi Dergisi, 15, pp. 63-77.

[25] Orlich, D., Harder, R. J., Callahan, R. C., Trevisan, M. S., \& Brown, A. H. (2010). Teaching strategies: A guide to effective instruction ( $9^{\text {th }}$ ed.). Boston: Wadsworth Cengage Learning.

[26] Wolhuter, C. C. (2015). Request for an international survey of the teaching profession. Education and Teacher Education in the Modern World Problems and Challenges. Chapter 1. (pp. 17-22). ISBN (10): 1-4438-8004-3; ISBN (13): 978-1-4438-8004-6 Editors: K.G. Karras, P. Calogiannakis, C. C. Wolhuter \& D. Kontogianni. UK: Cambridge Scholars Publishing. 